Andrea Mervar and James E. Payne

\title{
An Analysis of
}

Foreign Tourism Demand

for Croatian Destinations:

Long-Run Elasticity Estimates

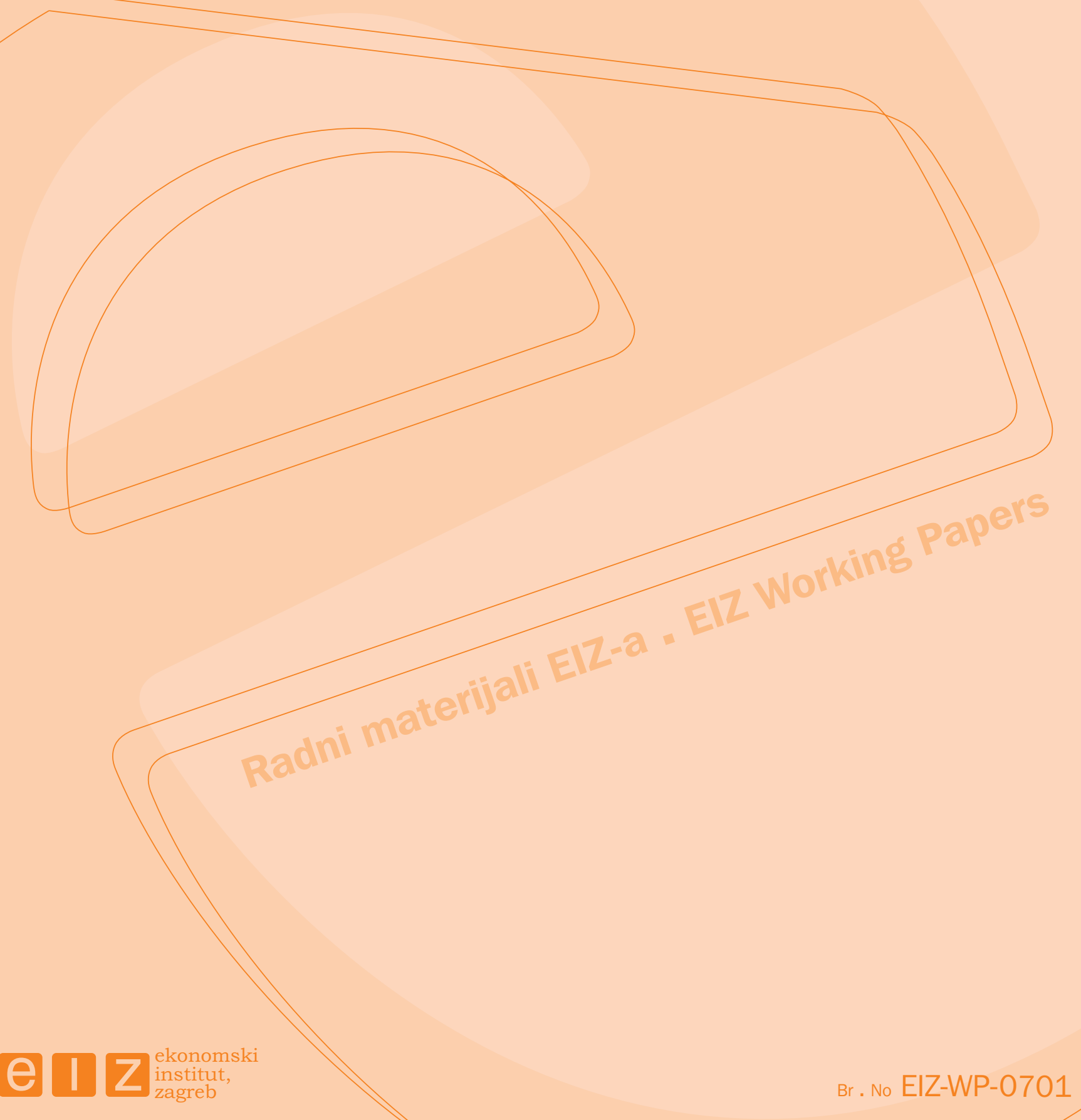




\title{
Radni materijali ElZ-a \\ EIZ Working Papers \\ EIZ-WP-0701
}

\section{An Analysis of Foreign Tourism Demand for Croatian Destinations: Long-Run Elasticity Estimates}

\author{
Andrea Mervar \\ Research Associate \\ The Institute of Economics, Zagreb \\ Trg J. F. Kennedyja 7 \\ 10000 Zagreb, Croatia \\ T. 38512362200 \\ F. 38512335165 \\ E. mervar@eizg.hr \\ and \\ James E. Payne \\ Professor and Chair \\ Department of Economics \\ Illinois State University \\ Normal, IL 61790-4200, USA \\ T. 3094518588 \\ F. 3094388588 \\ E. jepayne@ilstu.edu
}

www.eizg.hr 


\section{IZDAVAČ / PUBLISHER:}

Ekonomski institut, Zagreb / The Institute of Economics, Zagreb

Trg J. F. Kennedyja 7

10000 Zagreb

Croatia

T. 38512362200

F. 38512335165

E. eizagreb@eizg.hr

www.eizg.hr

ZA IZDAVAČA / FOR THE PUBLISHER:

Sandra Švaljek, ravnateljica / director

GLAVNA UREDNICA / EDITOR:

Valerija Botrić

UREDNIŠTVO / EDITORIAL BOARD:

Ivan Damir Anić

Željka Kordej-De Villa

Edo Rajh

Paul Stubbs

IZVRŠNI UREDNIK / EXECUTIVE EDITOR:

Josip Šipić

\section{TEHNIČKI UREDNIK / TECHNICAL EDITOR:}

Vladimir Sukser

Tiskano u 100 primjeraka

Printed in 100 copies

ISSN 1846-4238

Stavovi izraženi u radovima u ovoj seriji publikacija stavovi su autora i nužno ne odražavaju stavove Ekonomskog instituta, Zagreb. Radovi se objavljuju s ciljem poticanja rasprave i kritičkih komentara kojima će se unaprijediti buduće verzije rada. Autor(i) u potpunosti zadržavaju autorska prava nad člancima objavljenim u ovoj seriji publikacija.

Views expressed in this Series are those of the author(s) and do not necessarily represent those of the Institute of Economics, Zagreb. Working Papers describe research in progress by the author(s) and are published in order to induce discussion and critical comments. Copyrights retained by the author(s). 
Contents

\begin{tabular}{llr}
\hline & Abstract & 5 \\
\hline $\mathbf{1}$ & Introduction & $\mathbf{7}$ \\
\hline $\mathbf{2}$ & Literature Background & $\mathbf{8}$ \\
\hline $\mathbf{3}$ & Data, Methodology, and Results & $\mathbf{1 1}$ \\
\hline $\mathbf{4}$ & Concluding Remarks & $\mathbf{1 6}$ \\
\hline & Appendix & 17 \\
\hline & References & 20
\end{tabular}




\begin{abstract}
:
Given that tourism is a significant source of export revenues for Croatia, it is vital for policymakers to understand the factors affecting foreign tourism demand for Croatian destinations. This study provides long-run elasticity estimates associated with the aggregate foreign tourism demand for Croatian destinations in the period 1994:1-2004:4 using the autoregressive distributed lag (ARDL) approach. Foreign tourism demand is proxied by the aggregate number of foreign overnight stays in Croatia. The long-run elasticity estimates indicate that tourism demand is positive and highly elastic with respect to the income of tourist-generating countries. Moreover, tourism demand is adversely affected by the political conflicts in the 1990s. The real exchange rate and transportation costs are not statistically significant determinants of foreign tourism demand.
\end{abstract}

Keywords: tourism demand, cointegration, ARDL, Croatia

JEL classification: C220, L830

Analiza inozemne turističke potražnje za odredištima u Hrvatskoj: ocjene dugoročnih elastičnosti

\title{
Sažetak:
}

U Hrvatskoj je turizam značajan izvor izvoznih prihoda pa je stoga važno da nosioci ekonomske politike poznaju faktore koji utječu na inozemnu turističku potražnju za hrvatskim odredištima. U radu se ocjenjuju dugoročne elastičnosti ukupne inozemne turističke potražnje u razdoblju od prog tromjesečja 1994. do četvrtog tromjesečja 2004. godine, pri čemu je primijenjena Pesaran-Shin-Smithova metoda testiranja kritičnih vrijednosti (autoregressive distributed lag bounds testing). Ukupni broj noćenja inozemnih turista aproksimira inozemnu turističku potražnju. Ocjene dugoročnih elastičnosti upućuju na zaključak da je inozemna turistička potražnja snažno pozitivno elastična u odnosu na dohodak glavnih emitivnih zemalja. Politički događaji u 1990-im godinama negativno su utjecali na potražnju, a realni devizni tečaj i troškovi prijevoza nisu statistički signifikantne odrednice inozemne turističke potražnje.

Ključne riječi: turistička potražnja, kointegracija, ARDL, Hrvatska

JEL klasifikacija: C220, L830 
In an economy, such as Croatian, in which a significant part of export revenues are due to foreign tourism, it is important for policymakers to understand the sensitivity of foreign tourism demand with respect to its main determinants. Therefore, the objective of this study is to identify the factors determining foreign tourism demand for Croatian destinations, as measured by the number of overnight stays by foreign visitors. The analysis focuses on the developments that occured during the last decade, namely during the period following the dissolution of the former Yugoslav federation, the war and the reemergence of Croatia as an independent country. In addition, the period of analysis coincides with the time when the Croatian economy achieved macroeconomic stability allowing for a more comprehensive methodological approach. ${ }^{1}$ Specifically, in order to determine long-run elasticity estimates associated with foreign tourism demand in the 1994:1-2004:4 period, the autoregressive distributed lag (ARDL) approach to cointegration is employed.

To illustrate the importance of the tourism sector for the Croatian economy as well as the developments that took place over the past decade it should be mentioned that foreign tourism receipts increased substantially to roughly EUR 5.5 billion (US\$ 6.7 billion) in 2004, which represents about 20 percent of GDP and is almost four times the amount earned in 1994. At the same time, foreign tourism receipts made up 40 percent of the total export revenues of the Croatian economy. ${ }^{2}$ Furthermore, the labor force survey data suggest that in 2004 approximately 5.5 percent of employed persons in Croatia worked directly in the tourism industry. ${ }^{3}$

While the number of overnight stays by foreign visitors reached almost 43 million in 2004, three times the number achieved in 1994, historical highs from the late 1980s have not been surpassed. Traditionally, Western Europe has been Croatia's largest source market. Tourists from Germany and Italy account for one-third of the total number of overnight stays. When tourists from Slovenia, Czech Republic, Austria and Hungary, other major tourism export markets, are added, close to three-fourths of the total number of overnight stays stem from these countries. ${ }^{4}$

The paper is organized as follows. Section 2 reviews the literature on modeling tourism demand, while Section 3 gives details on data and the model specification along with a discussion of the empirical results. Section 4 provides concluding remarks.

\footnotetext{
${ }^{1}$ Readers unfamiliar with the economic developments in Croatia during the 1990s and the stabilization program introduced in October 1993 are recommended to refer to Anušić et al. (1999).

${ }^{2} \mathrm{CNB}(2006)$.

${ }^{3}$ CBS (2006).

${ }^{4}$ CBS (2005).
} 


\section{Literature Background}

In general, the literature on modeling tourism demand focuses either on analyzing the effects of various determinants and/or on accurate forecasting of the future tourism demand. This study lies within the group focusing on the underlying determinants. Comprehensive reviews of the empirical literature on tourism demand by Crouch (1994a, 1994b, 1995), Witt and Witt (1995), Lim (1997, 1999) and Li et al. (2005) suggest a substantial agreement regarding both the tourism demand measures and the variables that are important in explaining international tourism flows. ${ }^{5}$ Most of the existing empirical studies have used tourist arrivals/departures and tourism receipts/expenditures as dependent variables. The number of overnight stays and the average length of stay have also been studied, but much less frequently. As for the explanatory variables, empirical models of tourism demand borrow heavily from the consumer theory which predicts that the level of consumption depends on the consumer's income, the price of the good/service in question, the prices of related goods (substitutes and complements), and other demand shifters. As a result, income and prices are the most commonly used variables in terms of the major factors influencing tourism demand.

As leisure tourism is generally regarded a luxury good, the income remaining after expenditures on necessities, or the so-called discretionary income would be the preferred income variable. However, discretionary income is a subjective variable and is not precisely measurable. Therefore, most researchers have relied on the nominal or real (per capita) personal, disposable, or national income, as well as GDP as measures for income in origin countries.

Besides being sensitive to their own income, tourists are also sensitive to prices. Tourism includes two price elements: the cost of travel to the destination and the cost of living in the tourist destination. The literature shows that the most often employed variables aimed at measuring the cost of living at the tourist destination relative to the origin country (and possibly to alternative destinations) have been relative consumer price indices. However, their deficiency comes from the fact that the expenditure patterns of a tourist might be quite specific and therefore different from that of the average household in a certain country. As a result, some studies have used specific price indices such as hotel, drink and tobacco, shopping, meals, and entertainment price indices or the weighted prices of food, accommodation, transport, entertainment and other variables. It should be, however, noted that Martin and Witt (1987) report that such tourism-specific indices do not perform any better than the overall price indices.

Exchange rates often enter tourism demand models in addition to/or combined with relative price variables. Some researchers have even argued that tourists respond to exchange rate movements much more than to changes in relative inflation rates when they make decisions on the travel destination (Artus, 1972). However, Martin and Witt

\footnotetext{
${ }^{5}$ While Crouch (1994a, 1994b, 1995), Witt and Witt (1995), and Lim $(1997,1999)$ focus on studies published from the early 1960s up to the beginning of the 1990s, Li et al. (2005) review empirical studies in the post-1990 period.
} 
(1987) argue that the exchange rate alone is not an acceptable proxy for tourism costs. The majority of tourism demand models have employed the exchange rate adjusted for relative prices (i.e. real exchange rate) to capture the substitution between domestic vacations and international travel. In this way, the impacts of (relative) inflation and exchange rate movements are measured through a single variable.

Transportation costs have attracted much less attention in empirical studies basically due to a lack of precise measures for effective transportation costs. In countries where the majority of foreign tourists arrive by car, the proxy are usually oil or gasoline prices while in the case of far-off destinations, airline fares represent the preferable alternative. In the latter case, data problems arise due to the pricing practices of airlines that often include "special" fares which are difficult to collect and use for an empirical analysis. Furthermore, multicollinearity between the transportation cost and income variables presents an often cited reason for omitting the transportation cost variable from tourism studies (Lim, 1999).

In addition, the dynamics of tourism demand has been incorporated in studies to account for lagged effects due to supply constraints in the form of shortages in hotel accommodation, passenger transportation capacity and trained staff, which cannot be adjusted rapidly. Sometimes, a time trend is included to capture qualitative factors in the tourist destination or changes in tourist tastes for foreign travel. Finally, dummy variables are employed in order to capture the impact of wars, political crises or natural disasters, as well as seasonal variations.

In general, the international tourism demand model is typically estimated as a function of income of the origin country, relative prices, exchange rates, transportation costs between destination and origin as well as dummy variables and deterministic trends. Although annual data have dominated the research, quarterly observations have been more often used in the post-1990 studies in line with an increasing interest in the seasonality of international tourism flows (Li et al., 2005). Log-linear regressions are the most frequently employed functional forms as the estimated coefficients can be interpreted as elasticities. However, while traditional econometric techniques dominated studies up to the mid-1990s, the use of cointegration, VAR models, almost ideal demand systems, and time-varying parameter models have since become familiar approaches. ${ }^{6}$ This trend parallels the overall trend in applied economic studies since it has been shown that most time series data are not stationary and, therefore, the use of traditional econometric techniques may seriously affect the credibility of results.

As for the relative impact of major explanatory variables used in tourism demand studies, general conclusions indicate that income elasticity has commonly been found to be greater than one, confirming the luxury nature of tourism travel. The own-price elasticity is normally negative, although magnitudes vary considerably among studies. Generally,

\footnotetext{
${ }^{6}$ For a more detailed overview see Li et al. (2005).
} 
elasticity estimates show negative values ranging from 0 to -1 . Recent empirical studies that have undertaken the calculation of elasticities in both the short- and long-run show that the values of both income and own-price elasticites in the long-run are greater than their short-run counterparts, suggesting that tourists are more sensitive to income/price changes over the long-run ( $\mathrm{Li}$ et al., 2005). That is in line with the demand theory implying that consumption depends on what people expect to earn throughout a considerable period of time, while fluctuations regarded as temporary have less of an effect on their consumption spending. Theory also suggests a negative elasticity with respect to the other price variable, transportation costs. However, this variable is less frequently used in studies and the results vary to a large extent, not only by size and significance but also by sign. It may even be asserted that empirical studies do not fully support the view that foreign tourism demand is negatively related to travel costs.

\begin{tabular}{|c|c|c|c|c|}
\hline Authors & $\begin{array}{l}\text { Period and } \\
\text { frequency }\end{array}$ & Methodology & Dependent variable & $\begin{array}{l}\text { Explanatory } \\
\text { variables }\end{array}$ \\
\hline \multirow[t]{2}{*}{ Stučka (2000) } & \multirow[t]{2}{*}{$\begin{array}{l}\text { 1993:4-1999:2; } \\
\text { quarterly }\end{array}$} & \multirow[t]{2}{*}{ OLS } & $\begin{array}{l}\text { overnight stays by foreign tourists } \\
\text { (individual model for tourist demand } \\
\text { from Germany, Austria, Italy, } \\
\text { the Netherlands, Slovenia, Czech } \\
\text { Republic, Slovakia, Hungary and } \\
\text { Poland) }\end{array}$ & \multirow{2}{*}{$\begin{array}{l}\text { GDP of tourist- } \\
\text { generating } \\
\text { countries, relative } \\
\text { prices, nominal } \\
\text { exchange rate, } \\
\text { lagged dependent } \\
\text { variable }\end{array}$} \\
\hline & & & $\begin{array}{l}\text { arrivals by foreign tourists (individual } \\
\text { model for tourist demand from } \\
\text { Germany, Austria, Italy, } \\
\text { the Netherlands, Slovenia, Czech } \\
\text { Republic, Slovakia, Hungary and } \\
\text { Poland) }\end{array}$ & \\
\hline \multirow[t]{2}{*}{$\begin{array}{l}\text { Bellulo and } \\
\text { Križman (2000) }\end{array}$} & \multirow[t]{2}{*}{$\begin{array}{l}\text { 1994:1-1998:12; } \\
\text { monthly }\end{array}$} & \multirow{2}{*}{$\begin{array}{l}\text { Johansen- } \\
\text { Juselius } \\
\text { cointegration } \\
\text { procedure and } \\
\text { VECM }\end{array}$} & $\begin{array}{l}\text { overnight stays by foreign tourists } \\
\text { (individual model for tourist demand } \\
\text { from Slovenia, Italy, Germany and } \\
\text { Austria) }\end{array}$ & \multirow{2}{*}{$\begin{array}{l}\text { nominal and real } \\
\text { wages of tourist- } \\
\text { generating } \\
\text { countries }\end{array}$} \\
\hline & & & $\begin{array}{l}\text { arrivals by foreign tourists (individual } \\
\text { model for tourist demand from } \\
\text { Slovenia, Italy, Germany and Austria) }\end{array}$ & \\
\hline $\begin{array}{l}\text { Payne and Mervar } \\
\text { (2002) }\end{array}$ & $\begin{array}{l}\text { 1993:1-1999:4; } \\
\text { quarterly }\end{array}$ & OLS & total receipts from foreign tourism & $\begin{array}{l}\text { GDP of the } \\
\text { European Union, } \\
\text { real effective } \\
\text { exchange rate, } \\
\text { dummy variables }\end{array}$ \\
\hline
\end{tabular}

In light of the importance of the tourism industry for the Croatian economy, relatively little attention has been given so far to a quantitative analysis of this sector. The existing empirical research on international tourism demand has been limited and based on traditional econometric techniques such as ordinary least squares (Stučka, 2000 and Payne and Mervar, 2002) or more advanced econometric approaches such as the Johansen-Juselius cointegration approach (Bellulo and Križman, 2000). Table 1 reports the previously published studies of tourism demand in the case of Croatia. Two of the existing studies on tourism demand for Croatia (Stučka, 2000 and Bellulo and Križman, 2000) have modeled individual demand functions for the tourist-generating countries 
most important to Croatia. In both studies overnight stays and arrivals by foreign visitors were used as dependent variables. In contrast, Payne and Mervar (2002) modeled aggregate revenues from international tourism. In general, these studies found that the income of origin countries exerted a strong influence on tourism demand while price/exchange rate effects were often less conclusive.

This study aims to extend the tourism demand literature with respect to Croatia on several fronts. Firstly, due to methodological changes that frequently occurred in the balance of payments statistics in the past several years, the reliability of using foreign tourism revenues as a dependent variable is questionable. Furthermore, the number of tourist arrivals is also problematic in that the statistics may be inflated. For example, in the case of Croatia, if tourists change the place of their stay within the country, they are registered more than once in the statistics on tourist arrivals. Thus, the number of overnight stays circumvents these issues and also accounts for the length of stay although it excludes stays with friends and relatives or stays in other forms of unregistered accommodation. The aggregate number of overnight stays has not yet been used as a dependent variable in empirical studies. Secondly, the study extends the time frame of the analysis beyond 1999, the latest data used in published studies of foreign tourism demand in Croatia. Thirdly, unlike the previous studies, the autoregressive distributed lag (ARDL) bounds testing procedure advanced by Pesaran and Shin (1997) and Pesaran et al. (2001) is used to examine whether a long-run relationship between tourism demand and its determinants exists. ${ }^{7}$ As it is well known in the time series econometrics literature, unit root tests exhibit a low power, thus the appealing aspect of the ARDL approach is that various time series do not have to be integrated of the same order before implementing tests of cointegration.

\section{Data, Methodology, and Results}

Based on implications of the existing tourism demand literature and availability of data, the following empirical analysis employs foreign tourist overnight stays as a measure of tourism demand; various GDP measures of major tourist-generating countries as income measures, the real exchange rate as a measure of relative price and exchange rate effects, and oil prices as a proxy for transportation costs since the majority of tourists arrive to Croatia by car. In addition, it should be noted that during the 1994:1-2004:4 period, the Croatian tourism industry was twice strongly affected by politically-related events: in 1995 due to a military operation undertaken by the Croatian army to regain territories occupied in 1991, and in 1999 due to the Kosovo crisis and NATO intervention in the neighboring Serbia and Montenegro. Dummy variables are used to capture the effects of these one-off episodes.

\footnotetext{
${ }^{7}$ Recently, tourism demand functions using the ARDL technique were estimated for Turkey (Halicioglu, 2004) and Fiji
} (Kumar, 2004). 
Quarterly data for the 1994:1-2004:4 period are used in the analysis. The data are defined as follows: $q_{t}$ is the number of overnight stays by foreign tourists in Croatia, seasonally adjusted; $y_{t}^{j}$ is either seasonally adjusted real gross domestic product for the "old" 15 European Union members $\left(y_{t}^{E U 15}\right)$, members of the Euro Zone $\left(y_{t}^{E U Z}\right)$, or all 25 European Union members $\left(y_{t}^{E U 25}\right) ; x_{t}^{j}$ is either the index of the real effective exchange rate calculated with producer prices $\left(x_{t}^{X P P}\right)$ or the index of the real effective exchange rate calculated with consumer prices $\left(x_{t}^{X C P}\right)$; $o_{t}$ is the average world oil price per barrel in U.S. dollars; and $\varepsilon_{t}$ denotes random errors. ${ }^{8}$

\begin{tabular}{|c|c|c|c|c|c|c|}
\hline Variable & $\mathrm{ADF}(\mathrm{C})$ & $A D F(C+T)$ & $\mathbf{P P}(C)$ & $\mathbf{P P}(\mathbf{C}+\mathrm{T})$ & KPSS(C) & $\operatorname{KPSS}(\mathrm{C}+\mathrm{T})$ \\
\hline$q_{t}$ & -1.30 & -2.65 & -1.19 & -2.84 & $0.769^{a}$ & 0.089 \\
\hline$\Delta q_{t}$ & $-5.97^{\mathrm{a}}$ & $-5.88^{a}$ & $-6.19^{a}$ & $-6.04^{a}$ & 0.147 & --- \\
\hline$y_{t}^{E U 15}$ & -1.88 & -1.25 & -2.35 & -1.05 & $0.839^{a}$ & $0.173^{b}$ \\
\hline$\Delta y_{t}^{E U 15}$ & $-3.91^{a}$ & $-4.35^{a}$ & $-3.86^{a}$ & $-4.33^{a}$ & $0.395^{c}$ & 0.070 \\
\hline$y_{t}^{E U Z}$ & -1.98 & -0.81 & -1.83 & -0.99 & $0.838^{a}$ & $0.139^{\circ}$ \\
\hline$\Delta y_{t}^{E U Z}$ & $-4.98^{a}$ & $-5.29^{a}$ & $-4.98^{a}$ & $-5.23^{a}$ & 0.335 & 0.082 \\
\hline$y_{t}^{E U 25}$ & -1.28 & -1.19 & -1.59 & -0.93 & $0.838^{a}$ & $0.152^{b}$ \\
\hline$\Delta y_{t}^{E U 25}$ & $-3.43^{b}$ & $-3.62^{b}$ & $-3.35^{b}$ & $-3.56^{b}$ & 0.264 & 0.094 \\
\hline$x_{t}^{X P P}$ & -0.82 & -0.74 & -0.94 & -0.76 & 0.182 & $0.182^{b}$ \\
\hline$\Delta x_{t}^{X P P}$ & -2.54 & $-3.28^{c}$ & $-6.06^{a}$ & $-6.05^{a}$ & --- & 0.108 \\
\hline$x_{t}^{X C P}$ & -0.96 & -1.71 & -0.82 & -1.70 & $0.452^{c}$ & $0.157^{b}$ \\
\hline$\Delta x_{t}^{X C P}$ & $-6.48^{a}$ & $-4.24^{a}$ & $-6.51^{a}$ & $-6.41^{a}$ & 0.188 & $0.121^{c}$ \\
\hline$o_{t}$ & -0.35 & $-3.29^{c}$ & -1.08 & -2.12 & $0.617^{b}$ & 0.098 \\
\hline$\Delta o_{t}$ & $-3.91^{a}$ & --- & $-4.99^{a}$ & $-5.00^{a}$ & 0.079 & --- \\
\hline
\end{tabular}

Notes: Critical values for the $A D F(C)$ and $P P(C)$ unit root tests which include only a constant: a(1\%) -3.60, b(5\%), -2.93, and c(10\%) -2.60. Critical value for the $K P S S(C)$ unit root test which includes only a constant: a(1\%) 0.739, $b(5 \%) 0.463$, and $c(10 \%)$ 0.347. Critical values for the $A D F(C+T)$ and $P P(C+T)$ unit root tests which include both a constant and trend: a(1\%) -4.19, b(5\%) -3.52, and c(10\%) -3.19. Critical values for the KPSS(C $+T)$ unit root test which includes both a constant and trend: a(1\%) $0.216, b(5 \%) 0.146$, and $c(10 \%) 0.119$.

The analysis begins by investigating the unit root properties of the respective variables using the augmented Dickey-Fuller (ADF, 1979), Phillips-Perron (PP, 1988), and Kwiatkowski-Phillips-Schmidt-Shin (KPSS, 1992) unit root tests. The ADF and PP unit roots are based on the null hypothesis that the respective time series are difference stationary while the KPSS unit root test is based on the null hypothesis of trend

\footnotetext{
${ }^{8}$ Gross domestic product measures are in constant 1995 prices. Real effective exchange rate variables are based on indices, 1997=100. An increase in the real effective exchange rate means that the Croatian kuna is depreciating in real terms. Data sources are as follows: overnight stays by foreign tourists in Croatia (Croatian Central Bureau of Statistics), measures of gross domestic product (EUROSTAT), relative prices (Croatian Central Bureau of Statistics and OECD), real effective exchange rates (The Institute of Economics, Zagreb, Croatia), and the average world oil price per barrel (International Financial Statistics). All variables were converted to natural logarithms.
} 
stationarity. With the exception of the real effective exchange rate index calculated with producer prices $\left(x_{t}^{X P P}\right)$ and the average world oil price per barrel in U.S. dollars $\left(o_{t}\right)$, specifications of the ADF and PP unit root tests with a constant as well as a constant and trend indicate that variables are integrated of order one. However, the results for the KPSS unit root tests are quite diverse. Indeed, the unit root tests indicate varying orders of integration.

While the Engle-Granger (1987) and Johansen-Juselius (1990) cointegration procedures require the respective time series to be integrated of order one, the appealing aspect of the ARDL approach is that a long-run relationship can be established without pre-testing the respective time series for unit roots, which is useful given a relatively low power of unit root tests. This procedure begins by estimating a conditional ARDL-ECM model as follows:

$$
\begin{aligned}
\Delta q_{t}=\alpha_{0} & +\alpha_{1} D 95+\alpha_{2} D 99+\sum_{i=1}^{n} \gamma_{i} \Delta q_{t-i}+\sum_{i=0}^{p} \delta_{i} \Delta y_{t-i}^{j}+\sum_{i=0}^{q} \varphi_{i} \Delta x_{t-i}^{j}+\sum_{i=0}^{s} \psi_{i} \Delta o_{t-i} \\
& +\pi_{1} q_{t-1}+\pi_{2} y_{t-1}^{j}+\pi_{3} x_{t-1}^{j}+\pi_{4} o_{t-1}+\varepsilon_{t}
\end{aligned}
$$

where $\Delta$ is the first-difference operator; $\alpha_{0}$ is a drift component; $D 95$ is a dummy variable 1.0 for the military action undertaken by Croatian authorities in 1995:2 through 1995:4 to regain the territory occupied in 1991, and 0.0 otherwise; $D 99$ is a dummy variable 1.0 for the Kosovo crisis in 1999:2 through 1999:4, and 0.0 otherwise; and $\varepsilon_{t}$ are random errors.

In order to determine the presence of a long-run relationship, two tests are conducted. Firstly, the null hypothesis of no cointegration $\left(H_{0}: \pi_{1}=\pi_{2}=\pi_{3}=\pi_{4}=0\right)$ is tested against the alternative hypothesis of cointegration $\left(H_{A}: \pi_{1} \neq 0, \pi_{2} \neq 0, \pi_{3} \neq 0, \pi_{4} \neq 0\right)$ via a partial F-test. However, as discussed by Pesaran et al. (2001), the asymptotic distribution of the F-statistics is non-standard, regardless of whether the variables are $\mathrm{I}(0)$ or I(1). Pesaran et al. (2001) provide lower and upper bound critical values, where the lower bound critical values assume that all variables are $\mathrm{I}(0)$ while the upper bound critical values assume that all variables are I(1). If the calculated F-statistics is above the upper critical value, the null hypothesis of no cointegration can be rejected notwithstanding the orders of integration of the respective variables. If the calculated F-statistics is below the lower critical value, the null hypothesis of no cointegration cannot be rejected. However, if the calculated F-statistics falls between the lower and upper critical values, the result is inconclusive. Secondly, a t-test for the null hypothesis of no cointegration $\left(H_{0}: \pi_{1}=0\right)$ is conducted with respect to the lagged level of the number of overnight stays by foreign tourists in Croatia. 


\begin{tabular}{|c|c|c|c|}
\hline \multicolumn{4}{|c|}{ Table 3 ARDL Bounds Testing Procedure: Tests of Long-Run Relationships } \\
\hline Lagged Levels & Lags & F-Statistics & t-statistics \\
\hline$\left(q_{t-1}, y_{t-1}^{E U 15}, x_{t-1}^{X P P}, o_{t-1}\right)$ & 1 & $9.46^{\mathrm{a}}$ & $-4.77^{\mathrm{a}}$ \\
\hline$\left(q_{t-1}, y_{t-1}^{E U 15}, x_{t-1}^{X C P}, o_{t-1}\right)$ & 2 & $4.78^{\mathrm{b}}$ & -2.51 \\
\hline$\left(q_{t-1}, y_{t-1}^{E U Z}, x_{t-1}^{X P P}, o_{t-1}\right)$ & 2 & $7.63^{\mathrm{a}}$ & $-4.94^{\mathrm{a}}$ \\
\hline$\left(q_{t-1}, y_{t-1}^{E U Z}, x_{t-1}^{X C P}, o_{t-1}\right)$ & 1 & $4.46^{\mathrm{b}}$ & -3.41 \\
\hline$\left(q_{t-1}, y_{t-1}^{E U 25}, x_{t-1}^{X P P}, o_{t-1}\right)$ & 2 & $9.95^{\mathrm{a}}$ & $-4.78^{\mathrm{b}}$ \\
\hline$\left(q_{t-1}, y_{t-1}^{E U 25}, x_{t-1}^{X C P}, o_{t-1}\right)$ & 1 & $5.13^{\mathrm{b}}$ & -2.79 \\
\hline
\end{tabular}

Notes: Reported critical values are stated as the lower bound and upper bound for $k=3$. Critical values for the partial F-statistics were obtained from Pesaran et al. (2001, p. 300, Table CI(iii) unrestricted intercept and no trend): $1 \% 4.29$ to 5.61, 5\% 3.23 to 4.35, and 10\% 2.72 to 3.77. Critical values for the t-statistics were obtained from Pesaran et al. (2001, p. 303, Table CI(iii) unrestricted intercept and no trend): $1 \%-3.43$ to $-4.37,5 \%-2.86$ to -3.78 , and $10 \%-2.57$ to -3.46 . Significance levels are denoted by the following: $a(1 \%), b(5 \%)$, and $c(10 \%)$.

Table 3 reports the partial F-statistics associated with the lagged levels of the specified variables along with the t-statistics on the lagged level of overnight stays by foreign tourists in Croatia $\left(q_{t-1}\right)$ for up to 2 lags. ${ }^{9}$ For both lags 1 and 2, the partial F-statistics is statistically significant at the 10 percent level or better. The t-statistics on the lagged level of overnight stays by foreign tourists in Croatia $\left(q_{t-1}\right)$ is statistically significant at the 5 percent level or better with 1 lag, but not with 2 lags. The results suggest that a long-run equilibrium relationship exists with respect to the various determinants of overnight stays by foreign tourists in Croatia. Given the results of the ARDL bounds testing procedure, the ARDL model (Pesaran and Shin, 1997; Pesaran et al., 2001) is specified in a general form to illustrate the derivation of the long-run elasticity estimates:

$\alpha(L, P) y_{t}=a_{0}+\sum_{i=1}^{k} \beta_{i}\left(L, q_{i}\right) x_{i t}+\lambda^{\prime} w_{t}+\varepsilon_{t}$

where $L$ is a lag operator; $y_{t}$ is a dependent variable; $a_{0}$ is a constant term; $w_{t}$ is a vector of deterministic variables; $\alpha(L, P) y_{t}=1-\alpha_{1} L-\alpha_{2} L^{2}-\ldots-\alpha_{p} L^{p} ;$ and $\beta_{i}\left(L, q_{i}\right)=\beta_{i 0}+\beta_{i 1} L+\beta_{i 2} L^{2}+\ldots+\beta_{i q_{i}} L^{q_{i}}$. The long-run elasticity estimates are derived as follows:

$\hat{\phi}_{i}=\frac{\hat{\beta}_{i}\left(1, \hat{q}_{i}\right)}{\hat{\alpha}(1, \hat{p})}=\frac{\hat{\beta}_{i 0}+\hat{\beta}_{i 1}+\ldots+\hat{\beta}_{i \hat{q}_{i}}}{1-\hat{\alpha}_{1}-\hat{\alpha}_{2}-\ldots-\hat{\alpha}_{p}}$

where $\hat{p}$ and $\hat{q}$ are the estimated values of $p$ and $q$ with $i=1,2, \ldots, k$. In terms of deterministic variables, the long-run coefficients are derived as follows:

\footnotetext{
${ }^{9}$ In each case there is evidence of a long-run relationship between total overnight stays and various variables. Furthermore, the empirical results (available upon request) with respect to the alternative measures of income, real exchange rates, and the price of oil are considered long-run forcing variables.
} 
$\hat{\kappa}=\frac{\hat{\lambda}\left(\hat{p}, \hat{q}_{1}, \hat{q}_{2}, \ldots, \hat{q}_{k}\right)}{1-\hat{\alpha}_{1}-\hat{\alpha}_{2}-\ldots-\hat{\alpha}_{\hat{p}}}$

where $\hat{\lambda}\left(\hat{p}, \hat{q}_{1}, \hat{q}_{2}, \ldots, \hat{q}_{k}\right)$ are the ordinary least squares estimates of $\lambda$ in equation (2) for the selected ARDL model. The long-run coefficients are computed as shown in Table 4 (see Appendix). The selection of order of the ARDL model for the computation of the long-run coefficients is based on Akaike's information criteria up to two lags. ${ }^{10}$

The dummy variable, $D 95$, for the military action undertaken by Croatian authorities in 1995 to regain the territory occupied in 1991 is negative and statistically significant at the 1 percent level in every model with the parameter estimates ranging from -0.54 to -0.66 . On the other hand, although the dummy variable, D99, for the Kosovo crisis in 1999 is always negative, it is statistically significant at least at the 10 percent level in only four of the twelve cases with the parameter estimates exhibiting a greater range from -0.02 to -0.21 .

With respect to the impact of the tourist-generating countries income, the real gross domestic product is positive and statistically significant in all cases at the 1 percent level, no matter which proxy is used. In the case of the gross domestic product for the "old" 15 European Union members, $y_{t}^{E U 15}$, the parameter estimates range from 4.02 to 4.80 . When the real gross domestic product for the Euro Zone members, $y_{t}^{E U Z}$, is used as a proxy for income, the parameter estimates range from 3.36 to 4.29. In the case of the real gross domestic product for all 25 European Union members, the parameter estimates on income range from 4.35 to 5.01 . Based on the three alternative measures of income, it appears that the number of overnight stays by foreign tourists is highly income elastic.

In an attempt to recognize the role of currency fluctuations and relative prices on the demand for tourist destinations in Croatia, two alternative real exchange rate measures are used: the index of the real effective exchange rate calculated with producer prices, $x_{t}^{X P P}$, and the index of the real effective exchange rate calculated with consumer prices, $x_{t}^{X C P}$. With the exception of one case, the parameter estimates for these two measures are positive, meaning that the real depreciation of the Croatian kuna should have a positive impact on foreign tourist demand. However, the estimated parameters are statistically insignificant in all cases, suggesting that currency fluctuations and relative prices do not have a significant impact on tourism demand. Finally, the average world oil price per barrel in U.S. dollars, $o_{t}$, serving as a proxy for transportation costs, is negative in only two cases. In all other cases, the parameter estimates yield an incorrect coefficient sign and are statistically insignificant.

${ }^{10}$ Only 2 lags were used given a relatively short time horizon of the data set, not to mention the issue of degrees of freedom. For a more detailed look at the derivation of long-run estimates see Hendry et al. (1984). The estimates of asymptotic standard errors of the long-run coefficients are computed by the regression approach advanced by Bewley (1979). The ARDL computations were conducted using MICROFIT 4.0. 
This study examines the factors contributing to foreign tourism demand for Croatian destinations. Although the results are in line with the previous studies, this analysis extends the tourism demand literature on Croatia in several ways. Firstly, unlike in previous studies, the total number of overnight stays is used as a measure of tourism demand. Secondly, the analysis covers a longer time horizon than the previous studies on Croatian tourism. Thirdly, the autoregressive distributed lag (ARDL) bounds testing procedure is used to examine whether a long-run relationship between tourism demand and its determinants (long-run elasticity estimates) exists in order to circumvent a low power of standard unit root/cointegration tests. The long-run elasticity estimates indicate that foreign tourism demand is highly income elastic while the real exchange rate and transportation costs (proxied by oil prices) do not have any statistically significant impact on foreign tourism demand. With respect to the political climate in the region, it appears that the incidence of the war-related political instability either within the country or in the broader region adversely affected tourism demand for Croatian destinations. 


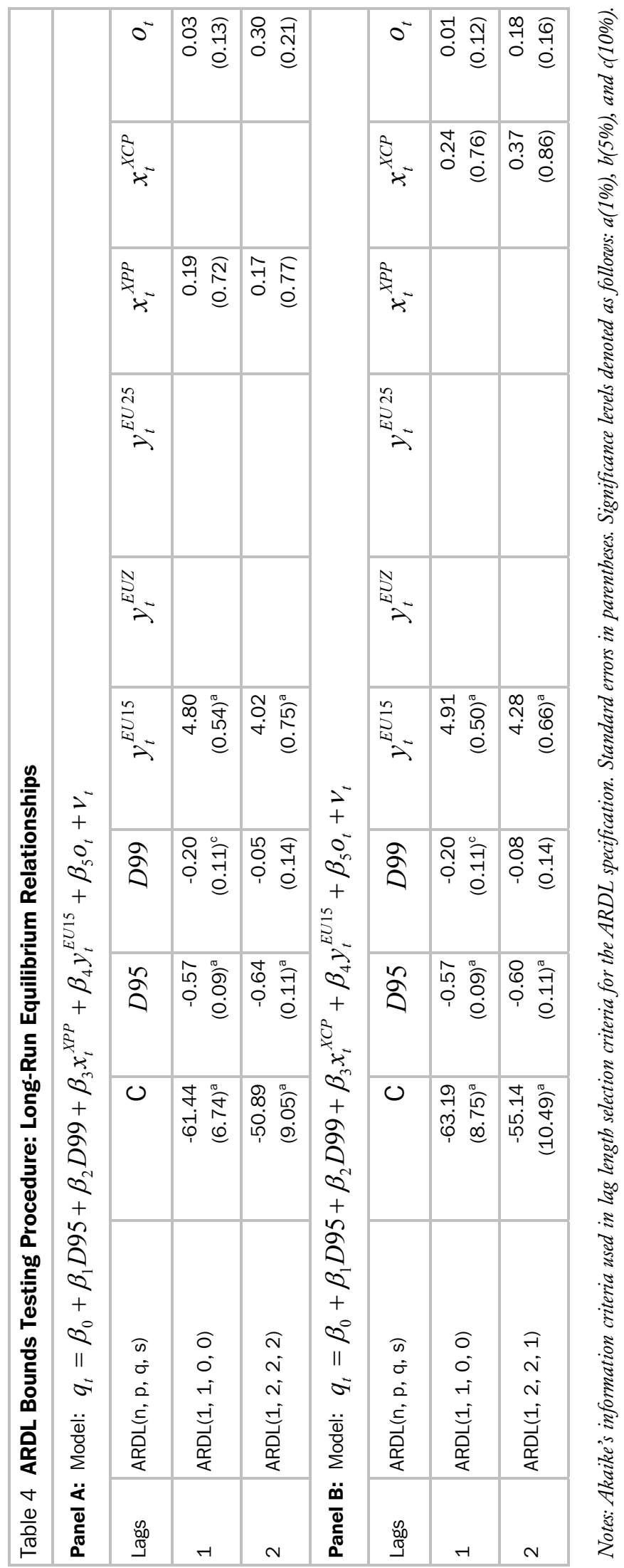




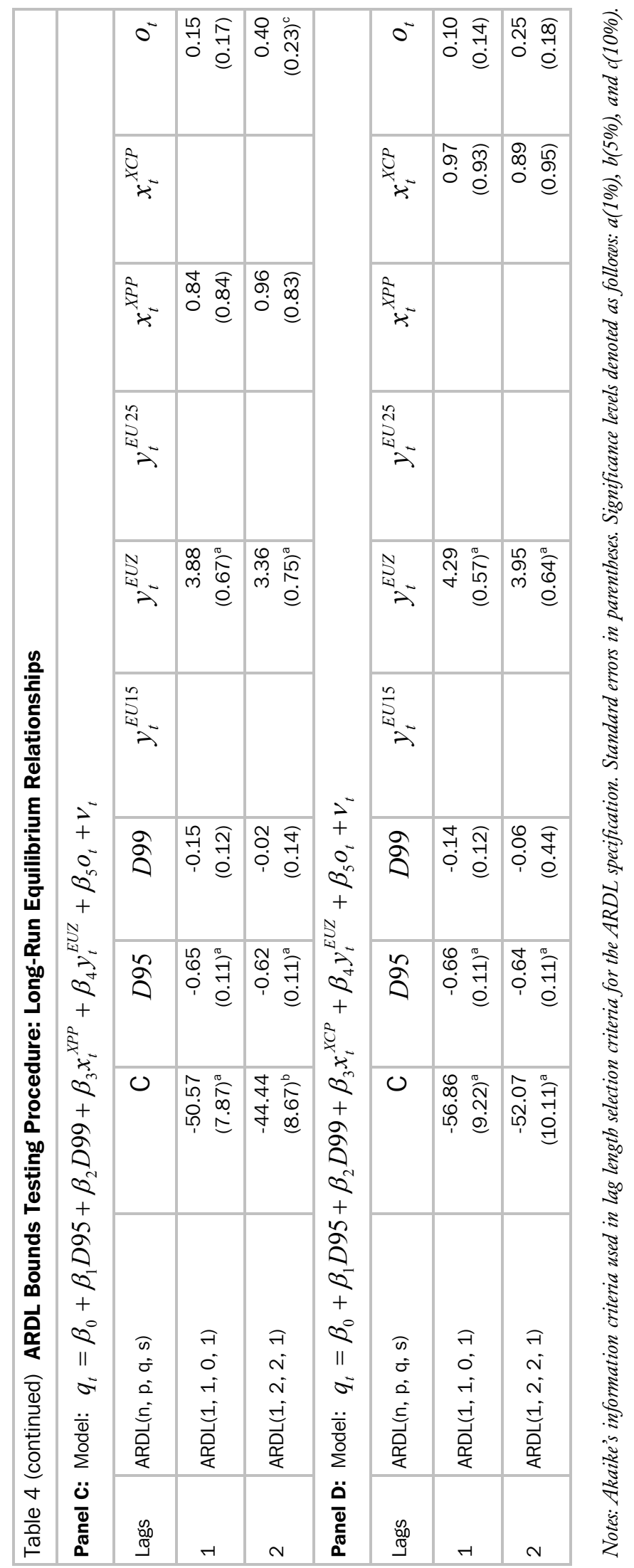




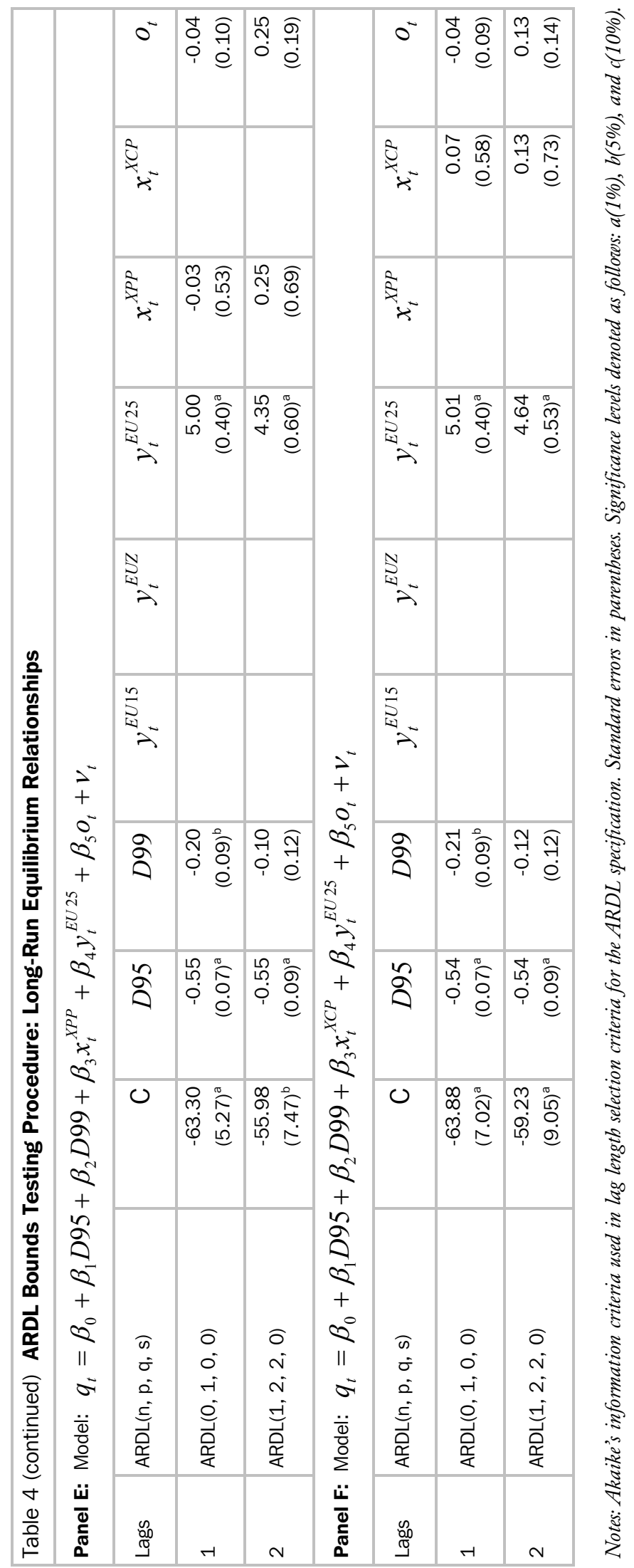


Anušić, Z., Ž. Rohatinski, and V. Šonje, 1995, A Road to Low Inflation: Croatia, 1993-1994, Zagreb: Government of the Republic of Croatia.

Artus, J. R., 1972, “An Econometric Analysis of International Travel”, International Monetary Fund Staff Papers, 19, pp. 579-614.

Bellulo, A. and D. Križman, 2000, "Utjecaj promjena u dohocima glavnih emitivnih zemalja na turistički promet u Hrvatskoj" ("Impact of Income Changes of Major TouristGenerating Countries on the Performance of Croatian Tourism"), Ekonomski pregled, 51(78), pp. 681-699.

Bewley, R., 1979, "The Direct Estimation of the Equilibrium Response in a Linear Dynamic Model”, Economics Letters, 55, pp. 251-276.

CBS, Central Bureau of Statistics, 2005, Statistical Yearbook, Zagreb: CBS.

CBS, Central Bureau of Statistics, 2006, "Labor Force Survey Results”, Statistical Report, No. 1277.

CNB, Croatian National Bank, 2006, Bulletin, No. 114, www.hnb.hr.

Crouch, G., 1994a , "The Study of International Tourism Demand: A Survey of Practice", Journal of Travel Research, 32, pp. 41-55.

Crouch, G., 1994b, "The Study of International Tourism Demand: A Review of Findings", Journal of Travel Research, 33, pp. 12-23.

Crouch, G., 1995, “A Meta-Analysis of Tourism Demand”, Annals of Tourism Research, 22(1), pp. 103-118.

Dickey, D. and W. A. Fuller, 1979, "Distribution of the Estimators for Autoregressive Time Series with a Unit Root", Journal of the American Statistical Association, 74, pp. 427431.

Engle, R. F. and C. W. J. Granger, 1987, "Co-integration and Error Correction: Representation, Estimating and Testing”, Econometrica, 55, pp. 251-276.

Halicioglu, F., 2004, “An ARDL Model of International Tourist Flows to Turkey”, Global Business and Economics Reviere, 2004 Anthology, pp. 614-624.

Hendry, D. F., A. R. Pagan, and J. D. Sargan, 1984, "Dynamic Specification", in Z. Griliches and M. D. Intriligator, eds., Handbook of Econometrics, Amsterdam: Elsevier, pp. 1023-1100.

Johansen, S. and K. Juselius, 1990, "Maximum Likelihood Estimation and Inference on Cointegration with Applications to the Demand for Money", Oxford Bulletin of Economics and Statistics, 52, pp. 169-210.

Kumar, N. P., 2004, "Fiji's Tourism Demand: The ARDL Approach to Cointegration", Tourism Economics, 10(2), pp. 193-206. 
Kwiatkowski, D., P. C. B. Phillips, P. Schmidt, and Y. Shin, 1992, "Testing the Null Hypothesis of Stationarity Against the Alternative of a Unit Root", Journal of Econometrics, 54, pp. 159-178.

Li, G., H. Song and S. F. Witt, 2005, "Recent Developments in Econometric Modeling and Forecasting", Journal of Travel Research, 44, pp. 82-99.

Lim, C., 1997, "Review of International Tourism Demand Models", Annals of Tourism Research, 24(4), pp. 835-849.

Lim, C., 1999, “A Meta-Analytic Review of International Tourism Demand”, Journal of Travel Research, 37, pp. 273-284.

Martin, C. A. and S. F. Witt, 1987, "Tourism Demand Forecasting Models - Choice of Appropriate Variable to Represent Tourists' Cost of Living", Tourism Management, 8(3), pp. 233-246.

Payne, J. E. and A. Mervar, 2002, "A Note on Modelling Tourism Revenues in Croatia", Tourism Economics, 8(1), pp. 103-109.

Pesaran, M. H. and Y. Shin, 1997, "An Autoregressive Distributed Lag Modelling Approach to Cointegration Analysis", in S. Strom, A. Holly and P. Diamond, eds., Centennial Volume of Ragnar Frisch, Econometric Society Monograph, Cambridge, UK: Cambridge University Press.

Pesaran, M. H., Y. Shin, and R. J. Smith, 2001, "Bounds Testing Approaches to the Analysis of Level Relationships", Journal of Applied Econometrics, 16, pp. 289-326.

Phillips, P. C. B. and P. Perron, 1988, "Testing for a Unit Root in Time Series Regression”, Biometrika, 75, pp. 335-346.

Stučka, T., 2000, "OLS model fizičkih pokazatelja inozemnog turističkog prometa na hrvatskom tržištu" ("Physical Indicators of Foreign Tourist Activity in Croatia: OLS Model”), Istraživanja, I-7, Croatian National Bank, September.

Witt, S. F. and C. A. Witt, 1995, "Forecasting Tourism Demand: A Review of Empirical Research", International Journal of Forecasting, 11, pp. 447-475. 
ISSN 1846-4238

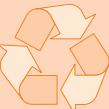

